\title{
Turán, Tamás and Carsten Wilke, eds. 2016. Modern Jewish Scholarship in Hungary - the "Science of Judaism" Between East and West. Berlin and Boston: De Gruyter Oldenbourg. 414 pages.
}

\section{Reviewed by David Mandler*, Stuyvesant High School, New York}

Much has been written about the German approach to studying Jewish texts known as Wissenschaft des Judentums since its inception almost two hundred years ago. From Max Weber's lecture in 1918 about Wissenschaft as a calling or a profession through Alexander Altmann's 1957 lecture "Jewish Studies: Their Scope and Meaning Today," which characterizes its impulses as contradictory (e.g. studying Jewish texts objectively while also engaging in apologetics), to Paul Mendes-Flohr's discussion of Weber and Altmann's work and overview of some major tenets of Wissenschaft des Judentums in his article, "Jewish Scholarship as Vocation" in Perspectives on Jewish Thought and Mysticism (Eds. Alfred L. Ivry et al.; London: Taylor and Francis, 1994, 33-48), generations of Anglophone readers have had ample access to insightful scholarly work on Wissenschaft des Judentums. The publishing house De Gruyter has also brought out such informative volumes on the subject as Gershom Scholem, die Wissenschaft des Judentums und der 'Ort' des Historikers ['Gershom Scholem, the Science of Judaism and the 'Place' of the Historian'] (2001), Jewish Existence in the Modern Age: Abraham Geiger and the Science of Judaism (2013), Aron Freimann und die Wissenschaft des Judentums (2014) and is scheduled to publish a volume entitled Wissenschaft des Judentums in Europe - Comparative and Transnational Perspectives in 2020.

Before the present volume, little had appeared in English about Hungarian contributions to Wissenschaft des Judentums. For example, Raphael Patai's Jews of Hungary: History, Culture, Psychology (Detroit, MI: Wayne State UP, 1996) offers brief biographical sketches of some Hungarian-Jewish practitioners (398-402). While much critical work has been done on the Budapest Rabbinical Seminary, mostly in Hungarian and some in English (see Kinga Frojimovics's "Teachers and Students: The Rabbinical Seminary of Budapest and the Neolog Jewish Legacy in Hungary" in From Breslau to Jerusalem - Rabbinical Seminaries: Past, Present, and Future, ed. Guy Miron; Jerusalem: The Schechter Institute, 2009 [Hebrew]), nothing definitive has appeared in English on the subject until now. Modern Jewish Scholarship in Hungary, edited by Tamás Turán and Carsten Wilke, not only provides wide contours in some areas of nineteenth-century Hungarian-Jewish scholarship but also some detailed biographical and scholarly sketches.

*Dmandler@schools.nyc.gov

(cc) $\mathrm{Br}$

ULLS D-Serle
New articles in this journal are licensed under a Creative Commons Attribution 4.0 International License.

This journal is published by the University Library System of the University of Pittsburgh as part of its D-Scribe Digital Publishing Program and is cosponsored by the University of Pittsburgh Press 
In their comprehensive Introduction, Turán and Wilke delineate the emergence of nineteenth-century Hungarian-Jewish scholarship by foregrounding five major enabling factors: traditional yeshiva education as a "common background of most rabbinical students," (2), the emergence of the Magyar language as a primary vehicle of scholarly work, the emotional intensity of Magyar nationalism fueled by a sense of exile and loss keenly felt by postemancipation Hungarian Jews, the development of Hungarian Orientalism "driven mostly by a search for cultural kinships and historical origins" (3), and the ascent of a centralized institution of the Hungarian Neolog community represented by the Rabbinical Seminary, which was founded in 1877. Scholars affiliated with the Rabbinical Seminary were ordained as rabbis with the notable exception of Ignác/Ignaz Goldziher (1850-1921), who was never trained as a rabbi. From the pioneers of Haskalah ['Jewish Enlightenment'], Aaron/Aron Chorin (1766-1844) and Moses Kunitz (1774-1837), through the reform-oriented rabbi Leopold Löw (1811-1875), continuing with the first three rectors of the Rabbinical Seminary: the Talmudist Moses Löb Bloch (1815-1909) and the two prolific scholars Wilhelm Bacher (1850-1913) and David Kaufmann (1852-1899), all the way to Sándor Scheiber (1913-1985), the editors take the reader by the hand on a grand historical tour.

Heavy on historical details, the Introduction also touches upon such thematic concerns as the "elusive historical-cultural concept" of Hungarianness in the Jewish context (17) and the ideological vs. pragmatic considerations of Hungarian-Jewish scholars of Judaism when choosing their language of scholarship. The Introduction also briefly alludes to Orthodoxy's vociferous opposition to historical criticism (23) and the Neolog tendencies to valorize culture over religion. The editors note that when the dust settled, some Neolog rabbis and scholars realized that, "their own 'educated public,' for whom they lectured and published, was more a fiction than a reality" (30). The bitter realization that this educated public was not interested in scholarly lectures on Jewish subjects, privately articulated by Goldziher in his diaries, was strongly echoed in a 1888 article in Magyar Zsidó Szemle by Rabbi Lipót Kecskeméti (18651936), here erroneously attributed to Rabbi Ármin Kecskeméti (1874-1944) in footnote 87 on page 30 .

This volume is based on an international conference representing scholars from half a dozen countries held in Budapest on October 14-16, 2012 and entitled Wissenschaft between East and West: The Hungarian Connection in Modern Jewish Scholarship. It contains seventeen highly informative articles and an interview with Chief Rabbi József Schweitzer (1922-2015), at that time the retired rector of the Rabbinical Seminary, to add up to a significant number in Jewish life: eighteen, or chai ['life']. While most likely unintentional, this number is very appropriate for a book that successfully unwraps the decaying shrouds of long-deceased rabbis and scholars, and which breathes new life into their work by repositioning it in a larger European context. The eighteen articles are grouped into six thematic clusters: Testimonies, Elective Affinities, Transnational Connections, Re-Orientalism, Untrodden Paths and Political Confrontations. While it would be worthwhile to discuss each article, the limited space allotted for this review and the enormous volume of historical facts marshaled in each one of them forecloses that possibility. Therefore, the fact that I exclude most articles in this cursory review should not be construed as a critique of their quality or worth.

Géza Komoróczy's article--which was the keynote lecture at the conference--entitled "The Rabbinical Seminary of Budapest and Orientalism Studies in Hungary" (37-54) not only 
provides a detailed overview of scholarly contributions emanating from the Rabbinical Seminary of Budapest but also refers to the dire state of affairs in current Jewish scholarship. The prolific Assyriologist and Hebraist, now in his eighty-first year, dutifully (and beautifully) touches upon the history of Hungarian Orientalism from the thirteenth to the twentieth century with historical precision and clarity. While most other articles in this volume also, rather repetitively, discuss both the genesis and the development of the Rabbinical Seminary and its luminaries, Komoróczy in addition sheds light on the diminished stature of Jewish Studies in Hungary following the absorption of the Center for Jewish Studies into an all-encompassing Institute for Minority Studies at the Hungarian Academy of Sciences in 2012. In effect, this inaugurating article helps to orient the reader into a book that will uncover an era of vibrant, rich and multifaceted scholarship practiced mostly by the doctor-rabbi scholars of the Rabbinical Seminary, an institution that after the Holocaust could never recover and return to its pre-war intensity, with the exception of Sándor Scheiber's exceptional scholarship. Komoróczy’s “good news” (54), namely that the Central European University, as he put it, "offers a Jewish Studies specialization at the MA and $\mathrm{PhD}$ levels" with an outstanding faculty (of which the co-editor and a contributor of this volume, Carsten L. Wilke, is an illustrious member) is, sorrowfully, presently tempered by the immediate prospects of CEU's viability in the face of the Hungarian government's declared opposition toward its continued existence in Budapest.

Carsten L. Wilke's meticulously researched article, "From Talmud Torah to Oriental Studies: Itineraries of Rabbinical Students in Hungary" (75-98), showcases the intersections between three divergent modes/institutions of Jewish scholarship: the yeshiva, the Seminary and the university. Wilke's main argument is that the "unabatedly traditionalist yeshiva system, a state-backed Rabbinical seminary, and the haughty scientism-including, at times, pseudoscientism - of Oriental studies at universities created an unmistakably Hungarian predicament of Jewish scholarship" (77). With the help of statistical data on the peregrinations, backgrounds, and placements of Neolog rabbinical students, along with the recollections of Bertalan Kohlbach (1866-1944) and Sámuel Löwinger's commemorative biography of Lajos Blau (1861-1936), an early rector of the Rabbinical Seminary, Wilke reconstructs the cultural milieu of late nineteenthcentury rabbinical studies in Hungary as compared to the rabbinical-studies landscape in Breslau and Prague. He notes that just as in Breslau's Seminary, many of the newly established Hungarian Rabbinical Seminary's students arrived with a strong background of traditional yeshiva education in the face of stiff opposition from their former teachers and colleagues. While the article makes clear that the most illustrious Talmudists of the school made use of their yeshiva background in their own studies, Wilke limits himself to making statements about various aspects of the work produced (focusing mostly on authorial circumstances) rather than producing textual analysis based on delving into a sample scholarly piece that could demonstrate the effects of the three different modes of knowledge acquisition he discusses.

Wilke is by no means alone in choosing to remain on the firm ground of historical overview instead of moving towards the more wobbly surface of textual analysis of primary sources produced by the nineteenth-century (rabbi-)scholars under scrutiny. In fact, many of this volume's contributors (mainly hailing from Jewish Studies departments) do so as well. Let us briefly and in no particular priority examine their contributions. Vilmos Voigt's "Suspension Bridge of Confidence" (108-118)) is about the place Jewish folklore studies occupied in the general landscape of Hungarian ethnography eventually focusing on the work of Friedrich 
Mandler, David. "Turán, Tamás and Carsten Wilke, eds. 2016. Modern Jewish Scholarship in Hungary - the "Science of Judaism" Between East and West. Berlin and Boston: De Gruyter Oldenbourg. 414 pages." Hungarian Cultural Studies. e-Journal of the American Hungarian Educators Association, Volume 11 (2018) DOI:

10.5195/ahea.2018.341

Salomon Krauss (1959-1938). Voigt, using as evidence the 1885 Hungarian National Exhibition in Budapest that did not showcase any "Jewish items," concludes that both Hungarians and Jews at that time conceived of Jewish folk-life "primarily not in terms of ethnicity, but in terms of religion" (114). Mirjam Thulin's "Wissenschaft des Judentums in the Hungarian Language?" (157-174) takes the life and prolific academic career of one of the many Moravian transplants to Budapest, David Kaufmann, rector of the Seminary, as its central focus without delving into any of his " 30 books and over 500 articles in just 25 years of literary activity" (YIVO encyclopedia, at: http://www.yivoencyclopedia.org/article.aspx/Kaufmann_David). Nonetheless, Thulin successfully sketches a careful portrait of a prominent Hungarian-Jewish scholar who facilitated connections among various centers of Wissenschaft de Judentums as co-editor of the influential monthly Monatsschrift für Geschichte und Wissenschaft des Judentums as of 1890 and, as Thulin puts it, "shaped the curriculum and trained the first generations of students at the Rabbinical Seminary in Budapest" (173). Catherine Hézser's “The International Context of Samuel Krauss's Scholarship" (175-192) takes another all-but-forgotten scholar, Samuel Krauss (1866-1948), and traces his intellectual development, which was heavily influenced by his university studies and exchanges with both Jewish and non-Jewish scholars (180).

Some of the contributors of this volume take as their central subject the works produced by the scholars they discuss. Without delving into particular passages, Günter Stemberger's "Meir Friedmann - A Pioneering Scholar of Midrash" (283-294) provides a thorough overview of Friedmann's work on late-antiquity to Medieval halakhic midrashim ['exegetic narratives' of halakha, Jewish Law]. He cites such work as Friedmann's editions of the Mekhilta de-Rabbi Yishmael (1870) with a collection of all quotations of Mekhilta de-Rabbi Shimon ben/bar Yohai, the Pesiqta Rabbati (1880), the Seder Eliyahu (1902) and what Stemberger sees as Friedmann's most important contribution, namely, his posthumous edition of the Sifra halakhic midrash of Leviticus. Isaiah M. Gafni's “Adolf Büchler and the Historiography of Talmudic Judaism” (295305) not only provides the fascinating scholarly trajectory of this Slovakian-born rabbi-scholar who studied in the Rabbinical Seminaries of Budapest and Breslau, the University of Leipzig, and Oxford, England, and later taught in Vienna and at the Jews' College in London, but also delves into the texts produced by Büchler. The result is a fascinating trip back in time as Gafni highlights Büchler's use of rabbinic sources in order "to rehabilitate the historicity of Rabbinic material, and to paint, from a sociological point of view, a far kinder picture of Judaism and its true leaders in the final days of the Second Temple" (298), thus reacting to harsh depictions of late-antiquity Judaism by non-Jewish scholars. Yet, in some issues Gafni opposes Büchler's depictions and theories of various historical phenomena excavated from halakhic sources by negating them with contemporary scholarly opinions (e.g. regarding some points about am haarets ['people of the land' lacking of traditional learning] groups in the Galilee around the time of Jesus).

Ismar Schorosch's substantial, thirty-seven-page article, "Beyond the Classroom: The Enduring Relationship between Heinrich L. Fleischer and Goldziher" (119-156), also provides primary evidence in the form of a selection from the two hundred and twenty letters between these two giants of Islamic Studies. Goldziher's life and work have been thoroughly discussed ever since scholarly interest in him revived after the Rabbinical Seminary's rector, Sándor Scheiber, published Goldziher's Tagbuch, his private diary, in 1978. Additionally, much of Goldziher's major work is in print and available to the general reading public. Raphael Patai's 
Mandler, David. "Turán, Tamás and Carsten Wilke, eds. 2016. Modern Jewish Scholarship in Hungary - the "Science of Judaism" Between East and West. Berlin and Boston: De Gruyter Oldenbourg. 414 pages." Hungarian Cultural Studies. e-Journal of the American Hungarian Educators Association, Volume 11 (2018) DOI: 10.5195/ahea.2018.341

Ignaz Goldziher and His Oriental Diary: A Translation and Psychological Portrait (Detroit, MI: Wayne State UP, 1986), Martin Kramer's Jewish Discovery of Islam - Studies in Honor of Bernard Lewis (Tel Aviv: The Moshe Dayan Center of Middle Eastern and African Studies, 1999), countless articles, my own work on the relationship between Goldziher and Vámbéry in Kelet és Nyugat mezsgyéjén. Vámbéry Ármin és a Brit Birodalom. (Budapest, Múlt és Jövő Kiadó, 2014) and its English original, Arminius Vambéry and the British Empire: Between East and West. (Lanham, MD: Lexington Books, 2016) all thoroughly discuss Goldziher. Nonetheless, Schorosch's account of the crucial help Fleischer provided Goldziher in keeping his spirit and self-belief intact in the face of the thirty-year derailment of his academic career following the political appointment of Péter Hatala as Chair of Oriental Studies at Budapest University, a position that the previous Minister of Education, József Eötvös, had promised Goldziher (see more on this on p. 127) coupled with slights, real and imagined, toward Goldziher's scholarly achievements, is wonderfully illuminated through the letters that Schorosch cites.

Tamás Turán’s lengthy article, “Academic Religion: Goldziher as a Scholar and a Jew” (223-270), rehearses some well-known biographical information already mentioned elsewhere (including in the article by Ottfried Fraisse preceding it in this volume), while also enhancing our understanding of Goldziher's pioneering adoption of "ethnographic and folkloristic methods" (252) in the treatment of religion in his academic work among other contributions Turán spells out with the care of a thorough historian. One might ask why Goldziher occupies one hundred and five pages (almost a third) of a book devoted to the Hungarian manifestations of Wissenschaft des Judentums, when Goldziher's most significant and enduring oeuvre relates to Islam. A sensible answer is that Schorosch, Fraisse (especially), and Turán discuss in detail the influence of Geiger's historical method and other scholarly approaches, which Goldziher picked up from Wissenschaft scholars and which, in part, enabled him to develop his own approach to studying Islam.

Miklós Konrád's "Hungarian Expectations and Jewish Self-Definitions, 1840-1914" (329-348) is an informative historical overview of the Hungarianization of Jews since Leopold Löw's (politically-motivated) insistence in 1844 that Jews "do not form a nation, but rather a community of faith" (339) to later race-based definitions, including the philosopher Bernát Alexander's argument for Jewish separateness (fully equipped with something he terms their unique "folk spirit" ['néplélek'] as their most efficacious way to contribute to Hungarian civilization) he put forth in as early as 1902 (345). To date, much of the material Konrád discusses still resonates. Therefore, contemporary Hungarian Jewish as well as non-Jewish readers interested in the definitions of Jewishness in the Hungarian context and the integration of Jews into Hungarian society will find much interest in his article.

Of equal interest to that raised by Konrád's work is András Kovács's article "The Decades of an Ending: The Budapest Rabbinical Seminary after the Shoah" (373-382). In it, Kovács makes excellent use of declassified intelligence dossiers complied by a certain Xavér on Sándor Scheiber. The meticulous examination of such sources helps the reader trace the devolution of the Seminary from an institution of scholarship vitalized by the intersections between yeshiva and university education (as some of the other articles in this volume clearly show) to a much diminished and compromised shadow of its former self, as a result of the wholesale destruction of all Jewish forms of life following the Holocaust coupled with strict 
communist control of Jewish religious and secular, cultural life (376). At a time of transition, as when Rabbi Alfréd Schőner gives up, effective July 1, 2018, the rectorship of the National Rabbinical Seminary renamed as Budapest University of Jewish Studies, and Professor Károly Vajda, a historian and the first non-rabbi ever to occupy this position, takes his place, Kovács's article may provide some perspective on what has led to the near extinction of current Hungarian rabbinical scholarship and, by extrapolation, what is needed to revitalize and redirect it within a modern context.

Finally, I would like to point out what to some may seem obvious and unproblematic: that the terms East and West in this book are used to demarcate geographic locations in an exclusively European context. Thus, the East is generally identified with Pressburg (Pozsony, Bratislava) and imbued with an uncompromising spirit of resistance to reforms led by Moses Schreiber (1762-1839), better known as the Chatam Sofer (who was, incidentally, born and raised in Frankfurt), while the West embodies the progressive spirit of Berlin and Breslau. Budapest is, therefore, depicted as an in-between space both geographically and in spirit. Readers excited by the subtitle of the book, The "Science of Judaism" Between East and West, who may be eager to find a more expansive treatment of these terms beyond such narrow definitions and constraints as geographical markers designating places in Europe and stereotypical attitudes associated with those places will find little to satisfy their curiosity. For those readers, an article reframing in postcolonial discourse the narratives about the nineteenthcentury scholars, rabbis, and scholar-rabbis, which the contributors to this volume excavated with the sharp tools of historical research (occasionally harkening to new-historicist methodologies), would have been a welcome addition. Nonetheless, this collection of eighteen articles not only moves us toward recovering a formative period of Hungarian Jewry with relevant implications to current Hungarian-Jewish life but it also highlights the extent to which rabbis, scholars (and rabbi-scholars) in or from Hungary influenced the field of Jewish Studies and its debates about Jewish religious and cultural life across Europe and beyond in the last two centuries. 